\title{
Welfare and Youth Work Practice
}


Welfare and Youth Work Practice is the second book in a series of three dealing with youth issues. The first book, Youth Work, was published in conjunction with the British Association of social workers. The third book will be Young People, Inequality and Youth Work. All three books are edited by Tony Jeffs and Mark Smith. 


\title{
Welfare and Youth Work Practice
}

\author{
Edited by
}

Tony Jefis and Mark Smith 
Selection, editorial matter, Chapters 1, 2, 3, 5, 12 and 13

(C) Tony Jeffs and Mark Smith 1988

Individual chapters (C) Duncan Scott with Neil Ritchie; Keith Shaw with Tony

Jeffs and Mark Smith; Howard Williamson; Robert Adams; Mary Marken and

Douglas Smith; Bernard Davies; Yusuf Ahmad and Ron Kirby 1988

All rights reserved. No reproduction, copy or transmission of this publication may be made without written permission.

No paragraph of this publication may be reproduced, copied or traismitted save with written permission or in accordance with the provisions of the Copyright Act 1956 (as amended), or under the terms of any licence permitting limited copying issued by the Copyright Licensing Agency, 33-4 Alfred Place, London WC1E 7DP.

Any person who does any unauthorised act in relation to this publication may be liable to criminal prosecution and civil claims for damages.

First published 1988

Published by

MACMILLAN EDUCATION LTD

Houndmills, Basingstoke, Hampshire RG21 2XS

and London

Companies and representatives

throughout the world

British Library Cataloguing in Publication Data

Welfare and youth work practice.

1. Social work with youth - Great Britain

I. Jeffs, Tony II. Smith, Mark, 1950 -

362.7'0941 HV1441.G7

ISBN 978-0-333-40982-4

ISBN 978-1-349-19309-7 (eBook)

DOI 10.1007/978-1-349-19309-7 


\section{Contents}

List of Tables

vii

List of Figures

viii

List of Abbreviations ix

Preface xii

Introduction $\quad 1$

1 Youth Work, Welfare, and the State 14

Tony Jeffs and Mark Smith

2 The Youth Service and the Threat to Welfare

41

Tony Jeffs and Mark Smith

3 The Political Economy of Youth Work

Tony Jeffs and Mark Smith

4 Local Authorities and Youth Work: the

Consequences of Declining Autonomy

90

Keith Shaw with Tony Jeffs and Mark Smith

5 Youth Work and Schooling

Tony Jeffs and Mark Smith

6 The DES and Youth Work

Duncan Scott with Neil Ritchie

7 Youth Workers, the MSC and the Youth Training Scheme

Howard Williamson

8 Finding a Way In: Youth Workers and Juvenile

Justice

Robert Adams 


\section{vi Contents}

9 Young People, Youth Workers and the Police Mary Marken and Douglas Smith

10 Professionalism or Trade Unionism? the Search for a Collective Identity Bernard Davies

11 Training the Professional Worker Yusuf Ahmad and Ron Kirby

12 The Promise of Management for Youth Work Tony Jeffs and Mark Smith

13 Conclusion

Tony Jeffs and Mark Smith

Notes on the Contributors 


\section{List of Tables}

6.1. DES funding to national voluntary youth organisations 1984-5

6.2. DES funding to 'top 10 ' national voluntary youth organisations $1973-4$ and 1984-5 


\section{List of Figures}

7.1 Policy-off youth unemployment and young people on special measures 


\section{List of Abbreviations}

$\begin{array}{ll}\text { ACC } & \text { Association of County Councils } \\ \text { ACW } & \text { Association of Community Workers } \\ \text { ADC } & \text { Association of District Councils } \\ \text { ADSS } & \text { Association of Directors of Social Services } \\ \text { AMA } & \text { Association of Metropolitan Authorities } \\ \text { APTC } & \text { Administrative, Professional, Technical and } \\ & \text { Clerical (related to local authority pay scales) } \\ \text { BYC } & \text { British Youth Council } \\ \text { CAB } & \text { Citizens' Advice Bureau } \\ \text { CDP } & \text { Community Development Project } \\ \text { CETYCW } & \text { Council for the Education and Training of Youth } \\ & \text { and Community Workers } \\ \text { CNAA } & \text { Council for National Academic Awards } \\ \text { CP } & \text { Community Programme (MSC) } \\ \text { CPRS } & \text { Central Policy Review Staff } \\ \text { CQSW } & \text { Certificate of Qualification in Social Work } \\ \text { CPF } & \text { Community Projects Foundation } \\ \text { CSE } & \text { Conference of Socialist Economists } \\ \text { CSS } & \text { Certificate in Social Service } \\ \text { CSV } & \text { Community Service Volunteers } \\ \text { CYSA } & \text { Community and Youth Service Association } \\ \text { CYWU } & \text { Community and Youth Workers' Union } \\ \text { DE } & \text { Department of Employment } \\ \text { DHSS } & \text { Department of Health and Social Security } \\ \text { DOE (NI) } & \text { Department of Education (Northern Ireland) } \\ \text { D of E } & \text { Duke of Edinburgh's Award Scheme } \\ \text { FE } & \text { Further Education } \\ \text { GRE } & \text { Grant Related Expenditure } \\ & \end{array}$




\begin{tabular}{|c|c|}
\hline GREA & Grant Related Expenditure Assessment \\
\hline HE & Higher Education \\
\hline HMI & Her Majesty's Inspectorate (Education) \\
\hline ILEA & Inner London Education Authority \\
\hline IMF & International Monetary Fund \\
\hline INSTEP & $\begin{array}{l}\text { In-service Training and Education Panel } \\
\text { (CETYCW) }\end{array}$ \\
\hline INTEP & Initial Training and Education Panel (CETYCW) \\
\hline IT & Intermediate Treatment \\
\hline JNC & $\begin{array}{l}\text { Joint Negotiating Committee for Youth Workers } \\
\text { and Community Centre Wardens }\end{array}$ \\
\hline LEA & Local Education Authority \\
\hline MAYC & Methodist Association of Youth Clubs \\
\hline MSC & Manpower Services Commission \\
\hline NABC & National Association of Boys' Clubs \\
\hline NACRO & $\begin{array}{l}\text { National Association for the Care and } \\
\text { Resettlement of Offenders }\end{array}$ \\
\hline NACYS & National Advisory Council for the Youth Service \\
\hline NAYC & National Association of Youth Clubs \\
\hline NAYCEO & $\begin{array}{l}\text { National Association of Youth and Community and } \\
\text { Education Officers }\end{array}$ \\
\hline
\end{tabular}

NAYLEA National Association of Youth Leaders in Local Education Authorities

NAYLO National Association of Youth Leaders and Organisers

NAYPCAS National Association of Young People's Counselling and Advisory Services

NAYSO National Association of Youth Service Officers NCVYS National Council for Voluntary Youth Services

NI Northern Ireland

NISW National Institute of Social Work

NUT National Union of Teachers

NVYO National Voluntary Youth Organisation

NYB National Youth Bureau

PHAB Physically Handicapped and Able-Bodied Clubs

PSBR Public Sector Borrowing Requirement

PSI Policy Studies Institute

RAT Racism Awareness Training

RTPI Royal Town Planning Institute

SCEC Scottish Community Education Council 
SCOYO Standing Conference of Youth Organisations (Northern Ireland)

SED Scottish Education Department

SSCVYO Scottish Standing Conference of Voluntary Youth Organisations

TAG Training Agencies Group (Initial Training)

TUC Trades Union Congress

TVEI Technical and Vocational Education Initiative

URDD Urdd Gobaith Cymru

UVP Unified Vocational Preparation

VPP Voluntary Projects Programme (MSC)

VSU Voluntary Services Unit (Home Office)

WOED Welsh Office Education Department

YMCA Young Men's Christian Association

YODU Youth Opportunities Development Unit (NYB)

YOP Youth Opportunities Programme

YSA Youth Service Association

YSIC Youth Service Information Centre

YSU Youth Service Unit (DES)

YTS Youth Training Scheme

YWCA Young Women's Christian Association 


\section{Preface}

This is the second of three books on contemporary youth work which, we hope, will collectively go some way towards stimulating the construction of a grounded theory and debate around youth work practice. Each of the three shares common elements, but they focus upon different facets of youth work. The first, largely written by practitioners, addresses theory and practice. The third is concerned with young people and inequality and the ways in which disadvantage is simultaneously reproduced and addressed within practice. In this middle book, youth work and the Youth Service are examined as an element of welfare.

The scale of the task means we have accumulated a number of debts. Firstly, we must thank the contributors, all of whom have been supportive and willing to endure rewrites. Secondly, a special thank you is needed to Jackie Kelly and Leslie Patrick for typing a number of manuscripts. Thirdly, we are indebted to Marion Leigh for providing a much needed critique of the text that focused our attention on a number of important areas. Fourthly, we must express our thanks to Jackie Apperley and Chris Rogers for their support and lack of any willingness to massage the pretensions of the editors. Fifthly, we are grateful to Alistair and Andrew Jeffs for being totally unthreatening and untroublesome adolescents (as far as we know), a constant and pleasant reminder that normality is the norm. Lastly, mention must be made of Alex and Christopher Rogers, who have, on occasions, had to put up with delayed meal-times, postponed outings and disrupted sleeping arrangements - victims of our anxiety to complete these books. The odd visit to McDonalds, we sense, hardly compensated for the disruption, but did at least spark serious debate concerning the ideologi- 
Preface xiii

cal correctness of the editors in one respect - a debate that has now been resolved following the introduction by the Wimpy Bar of beanburgers to their menu.

TONY JEFFS

MARK SMITH 